\title{
Instrumental Evaluation Methods: Why is it Difficult to use New Techniques?
}

\section{Document Version}

Accepted author manuscript

Link to publication record in Manchester Research Explorer

\section{Citation for published version (APA):}

Oulton, D. (1996). Instrumental Evaluation Methods: Why is it Difficult to use New Techniques? Textile Institute. Journal, 87(2), 399-400.

\section{Published in:}

Textile Institute. Journal

\section{Citing this paper}

Please note that where the full-text provided on Manchester Research Explorer is the Author Accepted Manuscript or Proof version this may differ from the final Published version. If citing, it is advised that you check and use the publisher's definitive version.

\section{General rights}

Copyright and moral rights for the publications made accessible in the Research Explorer are retained by the authors and/or other copyright owners and it is a condition of accessing publications that users recognise and abide by the legal requirements associated with these rights.

\section{Takedown policy}

If you believe that this document breaches copyright please refer to the University of Manchester's Takedown Procedures [http://man.ac.uk/04Y6Bo] or contact uml.scholarlycommunications@manchester.ac.uk providing relevant details, so we can investigate your claim.

\section{OPEN ACCESS}




\section{Letters to the Editor}

\section{Instrumental Evaluation Methods: Why is it Difficult to use New Techniques?}

\section{INTRODUCTION}

A recent paper [1] raises interesting questions on how complex computer systems can be used to provide important analyses of textile performance.

The problem is one of standardisation. It has been shown clearly over many years that test results can only be relied upon if carefully designed test procedures are published, and test methods carefully standardised. This works quite well for manual and visual methods.

Over a period of time, this position is gradually changing. Instrumental methods, calculated indices, and complex equations are being incorporated into new standard tests and test methods. The process by which a new equation, or simulation becomes generally adopted is long and tortuous. As computations and simulations become more and more complex, the potential for implementation error rises; so too does the difficulty of getting an innovative and useful system accepted and used.

If eventually we are to have available, and use, measures of all the more subtle textile properties, then they will no doubt be based on complex computer modelling, and analysis of multiple variables.

I wish to open a debate via the Journal of The Textile Institute on how best to reap the benefits of complex computer systems in textile testing, analysis and design.

Already the field of colour measurement is suffering from too many equations and too little hard validation material. This in turn results in confusion and under-utilisation. As new textife evaluation methods arise from physical testing systems such as those of Kawabata, and from image analysis, the situation is likely to deteriorate.

On the one hand, we will have proprietary and secret systems, whose results can only be compared by those with access to the system. The MS 89 colour difference equation is a case in point.

On the other hand, genuine advances will be restricted to the research laboratory by lack of general acceptance, or difficulty of comparison.

\section{VALIDATION}

No advance in testing or analysis can be widely or generally adopted until it has been thoroughly validated against currently accepted practice. Those seeking to profit from such advances will go some way down this road, but they are unlikely to publish (or indeed analyse too deeply) the potential weaknesses.

Criteria for evaluating new testing and analysis methods are also unclear. It is first necessary to establish a base line for comparison. This more often than not involves evaluation of a manual or visual procedure. Complex statistical analysis may well be necessary of both the existing accepted method and the new candidate method. Substantial investment may be necessary in inter-laboratory trials and result analysis. The committees of the learned societies, and International standardising authorities do some of this work.

\section{A PROPOSED SOLUTION}

It would be to the benefit of all concerned if:

(a) new ideas for testing, analysis and characterisation of textiles could be thoroughly 
and publicly validated;

(b) such ideas could be brought into use with minimum delay; and

(c) a definitive certified version of the appropriate software was available for purchase and use.

To achieve these objectives on a global scale, or even a national scale would be an ambitious programme. It could also require extensive and costly laboratory facilities.

On a cost/benefit basis, however, there are clearly many interested parties who could (would?) contribute to the cost.

It would be necessary to have:

(1) a body of International standing to control and deliver the validation and certification;

(2) a budget to either execute or sub contract the necessary work; and

(3) a clear method of prioritising investigations based on industrial need, and/or novel potential.

There is reason to suppose that a carefully managed programme would:

(a) be self-financing, or even revenue earning;

(b) stimulate and deliver innovation;

(c) deliver direct benefits to the industry; and

(d) be a major influence in the development of International standards.

\section{REFERENCE}

[1] B. Xu and J.A. Reed. J. Text. Inst., 1996, 87, Part 1, 203.

Department of Textiles,

D.P. OULTON

University of Manchester Institute of Science and Technology,

4.6.1996

Manchester,

England

\section{The Use of Neural Nets to Predict Yarn Tensile Properties}

\section{INTRODUCTION}

Several authors have demonstrated the usefulness of neural nets to model the spinning process [ 1-3]. Ramesh et al. [3] have modelled the tensile properties of air-jet yarns. They claim that the error of prediction is less than the standard deviation of experimentation. In this letter, comments are made on these conclusions.

\section{DISCUSSION}

Comparing the prediction error with the standard deviation of experimentation must be done with care, in order to avoid comparison of nonequivalent values. On the evaluation methods used by Ramesh et al. [3], we would like to make some comments. 